\title{
DISCUSSING THE SOCIO-ECONOMIC IMPACTS OF TOURISM DEVELOPMENT PROJECTS BASED ON GOLF COURSES: THE PERSPECTIVE OF LOCAL STAKEHOLDERS
}

\author{
J.A. DOMÍNGUEZ-GÓMEZ ${ }^{1}$ \& A. VARGAS-SÁNCHEZ ${ }^{2}$ \\ ${ }^{1}$ Department of Sociology and Social Work, Univ. of Huelva (Spain). \\ ${ }^{2}$ Department of Companies Management and Marketing, Univ. of Huelva (Spain).
}

\begin{abstract}
In this paper, we present some results extracted from a social impact study carried out on a golf-based tourism development project (GBP). A phronetic approach is adopted, underpinned by case study methodology. The main objective of the article is to shed some light on the debate over the profitability of GBPs. To this end, firstly, we define GBP and briefly set out the sociological and economic reasons for their growth. Secondly, we describe the specific case studied and our analytical approach, based on (1) analysis of the financial balance and prospects of the business in question, and (2) qualitative analysis of the views of local stakeholders. Discussion of our data enables us to assess to what extent a GBP can be deemed beneficial or not, highlighting the need for holistic, multidimensional and locally-based analysis to suitably evaluate GBPs as an appropriate model for sustainable development.

Keywords: economic impact, environmental and social impact assessment; golf tourism, qualitative methodologies, sustainable development.
\end{abstract}

\section{INTRODUCTION}

It is well known that GBPs, like all environmental interventions, have varied consequences, both positive and negative, on different areas of the socio-environmental context $[1,2]$. The economic aspect of GBPs is normally assessed positively in the literature, stressing the potential tourist market tapped [3]. The current practice of environmental and social impact assessment evidences the need for contextual studies, that is, for taking local dimensions into account as key to analysis and forecasting, as key to the study's utility in decision making.

The analysis of stakeholders ( $\mathrm{SH})$ and sociopolitical relationships in the local area is crucial for an understanding of the phenomenon and in offering advice for decision making: which actors have an interest in the GBP, which reap economic benefits, and which are harmed. This is fundamental in assessing the sustainability of a project and it fits with the environment, and, in sum, to what extent it will contribute to sustainable local development [4].

The main objective of this paper is to shed some light on the debate over the profitability of GBPs, by means of a case-study approach. We use a methodology based on qualitative analysis of the views of local stakeholders. Thereafter, we explain the main outcomes: which Shs are, and which of them are not, perceived as beneficiaries from this type of project or see 
their interests harmed. Our conclusions highlight the importance of knowing the perspective of local SH in tourism-urban-development projects; and also the need for holistic, multidimensional and locally-based analysis to suitably evaluate GBPs as an appropriate model for sustainable development.

\section{TOURISM DEVELOPMENT PROJECTS BASED ON GOLF PROJECTS: THE SOCIOLOGICAL FOCUS}

GBPs can be defined as urban-tourism development initiatives, generally in coastal areas. They consist of (at the very least) one golf course accompanied by four and five-star hotels in tourist-complex format, combined with low-density, high-end residential estates. Therefore, three economic activities are related to GBP projects: hotelery, real estate and those related to golf as a sport. This is a very common pattern of development in many parts of the world, and particularly in the south of the Iberian Peninsula. Thus, the main distinguishing feature of a GBP is, precisely, the centrality of golf.

From the sociological point of view, the growth of golf can be explained by a range of different reasons, linked to global contemporary culture [5]. (1). It is an activity associated with higher social classes [6,7]. (2) It takes place in the open air and in contact with 'nature' [8] (this is a tourist-adapted nature [9], but symbolically associated with 'Mother Nature' through its main features, such as 'grass', 'greenery', 'trees', 'open air', etc.). (3) It is a healthy activity, and health is seen as a value in itself, as part of the enjoyment of life, in line with a 'healthy lifestyle'. (4) From the demographic point of view, the ageing of the population in the developed world fuels the potential demand for golf, since it also fulfils all the conditions necessary to be played by mature and elderly people. (5) The media both boost and reflect this social growth of golf, and multinational company sponsorship has driven the increase in media coverage (the Volvo Masters, the BMW Golf Cup, etc.).

These sociological reasons interact synergically with those of a more economic and touristic nature, which tend to be more voluntaristic and uppermost in the minds of developers and local administrations with interests in and/or responsibilities for land management [10]. In the south of Europe, golf is promoted as a deseasonalizing and diversifying factor for tourism. Quality of tourism use to be and additional argument, meaning that supply is directed towards clients of medium to high social class $[11,12]$.

Based on this more economical rationale, GBPs have been energetically promoted by both local administrations responsible for tourist management and developers. In the case of Spain, responsibilities for land management are mostly concentrated in the hands of the town and city councils. In municipalities where GBPs have been completed, the local administration has seen them as a valuable source of socioeconomic development, bringing income to city coffers from the sale of municipal land, taxes on construction (licences, fees, property tax), concessions (on municipal golf courses), etc.

The fact that golf has counted on a positive attitude from local administrations means that promoters see increased chances of success in negotiations over project development. GBPs are 'profitable for both parties'. In brief, this makes it easier to bend tight planning regulations and to free land for development in local planning ordinances. Also the actual building of the golf courses, housing developments, hotels and facilities is an attractive proposition for businesses in the sector, in addition to being a solid short-term argument justifying projects with the local authorities, due to the creation of employment and activity among local building and supply companies. 


\section{THE IMPORTANCE OF THE CONTEXT; OR THE NEED OF LOCALLY-BASED ANALYSIS}

As may be observed, here our definition of GBPs is markedly contextualized. In other words, we define GBPs according to the way this development model has been applied in the specific area of the south of the Iberian Peninsula. Furthermore, a review of the literature revealed that this definition of GBPs can be applied to contexts differing considerably in geographical terms but sharing the same fundamental features: the sociology of golf and the centrality of the sport as an argument promoting the model among local administrations and developers. Thus, we find examples of GBPs conforming to our definition worldwide: Korea [13], Australia [14], the USA [15], and so on. The results we present here are fruit of a social-scientific study grounded in three main theoretical-methodological principles: (1) what Gibbons called 'Mode 2' knowledge production [16] reflected in a phronetic approach to social science [17], where (3) the 'case study' method optimizes the utility of results for valid and reliable decision making [18].

Gibbons opposes 'Mode 2' scientific production to 'Mode 1', which entered into crisis with the acceleration of social complexity at the end of the 20th century. This increasing complexity resulted in the reduction of the functionality of traditional science. Social reality changes more quickly than Mode 1 science is capable of addressing it. The assumption that reality is objective, regular, and therefore explicable using stable models, involves a topdown approach with constantly decreasing applicability. Reality resists explanation and demands a shift from older models, which are reflected in a form of scientific production further and further removed from socially useful solutions, although still fully accepted within increasingly self-referential academic institutions.

Mode 2 adopts the natural alternative, a mode which is more consistent with social demands on the scientific system; it is a more contextualized, transdisciplinary form of knowledge production, adapted to the dynamism of its object, reflexive and responsible [19]. This mode produces more valid and reliable information for a more realistic and workable form of knowledge, more coherent and better suited to the solution of real problems. In development projects such as GBPs, it is extremely common to ignore the factors which give them real complexity and risk but are very rarely absent on the ground: i.e. social and cultural factors.

Therefore, in studying the economic dynamics created by GBPs, we cannot leave aside the play of relationships and interests at local level, nor their equivalents on a wider scale, should this be the case. The outcome is a reflexive and evaluative analysis, bringing fresh insights to the decision-maker, but also for all SHs involved in the GBPs. This phronetic approach to science, and especially social science [20], is highly practical, requiring familiarity with the object of study in its own context and situation. This type of knowledge concerns itself with the various differing logics affecting reality, stressing utility and the understanding of the object [21].

\section{OBJECTIVE AND METHODOLOGY}

The objective of this study is to enrich the debate on the profitability of GBPs; especifically, the assessments that SHs make of these GBPs, and for whom, and for what reasons, they are defined as beneficial, harmful or neutral. What we outline in this paper is part of a case study of a GBP centred on the El Molinillo golf course, located next to the fishing village of El Rompido in the municipality of Cartaya, Huelva (SW Spain). The methodology adopted was qualitative. To study SHs' views, we carried out a series of 26 semistructured interviews with a total of 15 local SHs (see Table 1). The interview enquired into the impacts 
Table 1: Number of interviews per stakeholder.

\begin{tabular}{ll}
\hline $\mathrm{n}$ & SH \\
\hline 2 & Regional Government \\
1 & Local Government \\
2 & Big hotels managers \\
2 & Small local businesses \\
1 & Tourist services and golf supliers \\
2 & Building and Real state entrepreneurs \\
1 & Agriculture entrepreneur \\
2 & Golf courses and hotels workers \\
2 & Bulding and real state workers \\
2 & Golfers \\
1 & Tourists (not golfers) \\
2 & Neighborhood associations \\
2 & Ecologists \\
2 & Local community \\
2 & Seasonal residents \\
\hline
\end{tabular}

Source: created by authors

caused by GBPs in the local area. The stakeholders were chosen by a total of six academics from the University of Huelva, local experts in diverse disciplines with a scientific interest in the risks and impacts of development projects: geography, economy, sociology, company management, development studies and ecology. The choice of interviewees (representatives of each $\mathrm{SH}$ ) was made through the collection of references in the field. Once transcribed, the interviews were analysed using Atlas.ti 7.0, a programme specialized in qualitative analysis [22].

The basic output used in our analysis was a concept map. A concept map or network is a cognitive or mental diagram representing relationships between concepts, or between patterns of concepts; also more generally understood as any explicit representation of the sets of conceptual meanings in a structure of subjects' mental propositions [23]. In this case, the diagram obtained represents how the various impacts of GBPs, perceived by the local SHs, are positioned and interrelated. We see the cognitive network as a reflection of the social discourses of the SHs, centred on GBP impacts. Each discourse belongs to a specific social grouping, understood as structured in and by daily social activity and constructed through the interaction of the individuals within the group [24].

For this study, the nodes of the concept map are the codes attributed to each element of the social discourses directly or indirectly associated to economic impacts. The links between codes, and their nature (cause, association, belonging and others) were inserted on the basis of the literal statements of informants, or by inference from these, following the precepts of Grounded Theory [25]. The data collection process (field work), transcription and analysis took place from May 2014 to June 2015. 


\section{THE CASE STUDY AND ITS CONTEXT}

Located in the coastal resort of El Rompido, in the municipality of Cartaya (province of Huelva, SW of Spain), the case study is a GBP with 36 holes over 50 hectares divided between two 18-hole courses (south and north1 opened in October 2003 and June 2006 respectively). The project, named EL Rompido Golf, partially abuts a thick pine wood on the south-western side, part of the Marismas del Río Piedras y Flecha de El Rompido Natural Area (an officially protected site), and orange groves on the northern side.

Hotels comprised in the complex include the Price Marismas Club aparthotel (four stars, with 305 apartments and 844 beds), and the Precise Hotel El Rompido (five stars, with 184 bedrooms and 12 suites; 394 beds in total) (Junta de Andalucía, n.d.), both of which are directly connected to the golf courses. There is full access to the complex, with proactive commercial promotion (attendance at specialized trade fairs in target countries, etc.) designed to attract what Villar-Lama [26] calls tourism golf, to contrast with other types.

The residential part of the project comprises firstly a housing development on its southeastern border: 165 luxury dwellings with independent gardens, laid out around an artificial lake, next to which is the golf club facility. Secondly, bordering this development to the east, on the far side of the road from El Rompido to Cartaya, there is the partially-built (construction halted due to lack of sales) El Rompido Marina estate, with 200 projected dwellings on independent plots with shared sports and leisure facilities (tennis and paddle tennis courts, football pitch, swimming pools, etc.).

Cartaya, the municipality where the scheme is located, adopted a tourist development strategy with a strong leaning towards GBP in the early 1990s2. Its geophysical environment is characterized by undulating terrain with few slopes, the mouth of the River Piedras, a wide expanse of pine woods, scrub and wetlands. The climate is Mediterranean, with mild winters and hot summers and an average annual temperature of around $23^{\circ} \mathrm{C}$ centigrade. In the last two decades, Cartaya has considerably increased its sociopolitical and economic weight in the province of Huelva, due to growth in agroindustry and associated activities. Cartaya has 19,168 registered inhabitants (2014), and in the last 10 years has increased its population by $29.8 \%$, mainly thanks to the growth in agriculture [27].

Until the mid-1990s, tourist facilities were virtually nonexistent. In El Rompido, a small fishing village on the coast, there was some residential sun-and-sand tourism, seasonal, lowintensity and basically local (from the provinces of Huelva and Sevilla). During the second half of the decade the town council, drawing on their regulatory powers and backed up by the regional administration of Andalusia, boosted tourist initiatives with a more mixed (GBPbased) model, more extensive and with lower density.

\section{RESULTS: THE VIEW OF STAKEHOLDERS}

Focusing now on the views of stakeholders sharing the terrain of this GBP, their group discourse both includes and differentiates the three sources of economic activity stemming from these projects. Golf courses, as part of the infrastructure developed in GBPs, were seen as drivers of tourist demand in general, linked to local 'development'. The concept of development referred to by SHs here was traditional, simple, and always understood as positive for the area, associated fundamentally with well-being and economic growth (without either environmental or social consequences). They saw this increase in tourist demand as boosting, indirectly, other activities, such as leisure sailing.

[No one can be against it because] we can't set ourselves against what development brings in this area or in any area. Local golfer. 
For the town it's been really beneficial because it gives us another chance, right? Local resident.

However, the environmental aggression seen in the construction of golf courses incited participants to call for alternatives to these infrastructures, for 'alternative developments' to the GBP model. One of the main values held dear by local SHs (especially seasonal tourists and local residents) was the 'traditional charm' of the area, closely linked in their minds with natural resources and traditional economic activities (sustainable exploitation of forests, family complementary agriculture, fishing and seafood), which they saw as representing a cultural heritage threatened with extinction.

[El Rompido] has changed a lot (...). The complexes are all fenced off, you can't get into them, so they've closed off a lot of the land, they've closed a lot of the town. Before, El Rompido was huge, it was big. The part out the back there, you could walk and run, people could pick mushrooms, pick asparagus. (...) Thanks to the golf courses there are more hotels and thanks to the hotels there's more tourism. It's like the end of the story. Local resident.

The positive view of the growth in tourism stemming from the golf courses clashed in the group mind with this 'traditional charm', made up of traditional activities, customs, landscapes and environment, in a context of low tourist density. This traditional charm was often cited as a tourist value, at the same time as participants appealed to the idea, essential according to some interviewees, of 'sufficient development:' the excess of GBPs was seen as an aggression against environmental and cultural resources that are highly valued by the local population, seasonal and residential tourists, and this excess was viewed as counterproductive, in economic and even ethical terms.

In 15 years this has been the change, because before there was nothing. There in the area around Marina El Rompido, it was all completely unspoilt, there was a kind of fort up there, there was nothing when we arrived (...) All the area round the mall, by the lighthouse, none of that existed. The new port didn't either. We had the old catamaran and we used to go over the other side constantly, right? Seasonal resident.

One central idea in the local collective mind was that golf tourism is independent of the community and has a scanty or almost non-existent effect on it. Golf tourists are almost $100 \%$ foreign, 'managed' in isolation by the tour operators and their hotels. The complaints of local businesses revolved around the fact that these tourists do not bring income to their establishments and services, since they very rarely leave the hotel-golf course complex, and when they do it is the tour operators and their licensees, always companies alien to the area, who take care of the business. This 'tour-isolation' acts as a brake on local enterprise in the area of new tourism businesses, and on new tourism services that local entrepreneurs might profit from. Further, economic activity linked to the sport of golf itself was not seen as beneficial to the local community, as essentially it is played by foreign 'tour-isolated' holidaymakers and the few Spanish golfers who 'come, pay the club, and leave'.

[The golf courses] don't have much effect either, they affect my brother (who works in a hotel), two or three boys from El Rompido, not El Rompido as a whole. Local resident.

Well think about it, we're right at the top of the peak season of the golf club. Look around you and tell me if there's a table here with golfers. There aren't any! (...) The people from there don't go out of there, so it doesn't benefit us. Local bar owner. 
Hotels and their activities are another defining feature of GBPs. Hotels not directly involved with the golf complex also provide services in all-inclusive, half board and bed and breakfast packs. These are sold in the holidaymaker's home country, and thus he or she rarely leaves the hotel facilities to use services not on offer there. This is especially true of the foreigners. It is the Spanish tourists who, on coming for subsequent stays, leave the hotel and its complementary services more often, essentially to eat out in the town. Non-golf hotel businesses only stay open between April and September, closing for the rest of the year. Traditional residential tourists and seasonal residents come to the area in these months. This results in an extreme seasonal bias, with restaurants full during the summer period but half-empty, even at weekends, during the rest of the year. This seasonal activity and the tourist isolation of the golf and its complex were the two important problems seen by local small businesses, basically in the restaurant sector and the few tourist service companies (taxis, ferries and outdoor tourism).

In the summer the town is overcrowded, and I mean overcrowded! (...). Well, compare it with the winter. Now in the winter you can count us on the fingers of one hand. On Saturdays and Sundays they have the best days and more people come, but don't imagine it's so many. I mean you can easily find a table. Seasonal resident.

[The tourists don't leave the hotels] much, in fact for them to come and do our activities (...) we go to the briefing they hold every Sunday morning. But anyway these people come almost always with their little everything-included bracelet and they hardly ever go out because they have activities every night. So the town, the shops, the restaurants, etc., these people hardly see any money from the French who stay the whole time inside the complex. Local tourist services entrepreneur.

The third group of economic activities linked to the GBPs, construction and property development, involves similar issues in the local group mind to those explained above. The positive contribution to the area's 'development' emerged indirectly, through its stimulus to tourist demand. Incomes produced for the town council through taxes on construction and property were positively valued. Participants also acknowledged that the GBPs had raised land values, with the result that the property market had yielded high profits for local proprietors of plots, homes and commercial premises. A few SHs remarked on the 'prestige' brought by luxury housing developments, declaring that 'they're good for El Rompido' in terms of its image as a tourist destination.

They started with [El Rompido Marina], which everyone knows cost a bomb. It's a really private estate, really exclusive, with an artificial lake, which was going to cost top prices (...) [Names various famous Spaniards] live there. (...) On that estate hardly anyone ever sees anyone who lives there, the only one was [names a celebrity] who I saw buying a newspaper... Local resident.

Generalized views that GBPs were 'good for the area' were only specified in terms of the increase in the restaurant trade - and thus of local business in this sector - and (informal) renting of homes. This 'general good' was contrasted with the loss of potential profits due to 'tour-isolation' and the building of high-end housing developments, both linked with certain 'private interests', seen as shady and dubious. After the financial crash of 2008 and the subsequent collapse in the property sector, this market has been excluded from local profit-making, and employment in the sector has been lost. Furthermore, the impact on the environment, a result of tourism expansion, was judged overall to be negative and harmful to the area. The 
perception of local SHs, as well as seasonal residents, was now more centred on nostalgia for the former conditions of their 'little fishing village'.

On the economic side I have the feeling that it's all in the service of outside capital. It brings jobs to the area because there can be workers, basically in the hotel and catering trade, from the area, but really the capital is from outside and I think the wealth created too, the exploitation of the area goes outside, eh! I don't see that Cartaya has improved its living standards. Local resident.

In the good years we built around 150 properties a year. Right now we haven't built anything for four years, ha-ha, and in Marina the rate was a bit higher but it stopped too when the crisis came along in 2008. Local construction entrepreneur.

\section{DISCUSSION AND CONCLUSIONS}

Different perspectives about the benefits of GBPs are founded. The benefits produced by GBPs for the local community, in terms of sustainable (in the contemporary meaning of the word: economical, environmental and social) local development, are questioned by the most of SHs. The construction sector, inactive since 2008, had up to that year acted as an economic outlet for small local businesses subcontracted in GBP development. The golf courses and new hotels provided the local community with very few jobs, most of them of poor quality. The tour-isolation regime benefits the hotel chains and, especially, the tour operators, and acts as a brake on the supply of complementary services by local entrepreneurs. Moreover, the boosting of tourist demand by the GBPs has not lessened the seasonality of the local holiday trade, since, with the exception of the five-star hotel on the golf course itself, this only operates in the summer period. The town of El Rompido has focused its supply on the mass seasonal hotel trade, dramatically reduced in winter months.

From an overall standpoint, and bearing in mind the development of the three economic activities of the GBPs in the area we have studied, these latter could be defined as a tourismurban-development option evolving from traditional residential tourism (solely based on 'sun and sand' and originating in the Levante region of Spain [28], towards a 'new residential tourism'. The typical features of this option are founded on values that are widespread in our society and aim to boost the tourism and property industries. As clear examples we could cite the values of 'quality' (which in practice becomes 'high spending power'), 'environment' and 'sustainability' (which in practice become 'landscaping') in development.

The data presented here evidence the promotion of residential and hotel development targeted at exclusive clients. It also shows how golf courses are angled towards a 'golf-tourism' format [26] which does not provide sufficient social or economic benefits for the local community. These risk factors in GBPs have been clearly pointed out in studies carried out worldwide $[14,29]$. That is the actual perceptions of most of local Shs.

The current situation, then, represents a new challenge to GBPs such as those defined here. In the particular case we analyse, only determined action on behalf of the regional and local administrations, in partnership with small businesses and local communities, can forge a strategic change in the tourism industry model towards truly sustainable values that can be beneficial to local business and development [30].

The qualitative results here stated should be complemented with further research, oriented to determine the economic impact, in money, for the different stakeholders. So difficult task would bring figures over the diverse perceptions here described. 


\section{REFERENCES}

[1] Del Campo Gomis, F.J., Molina Huertas, M.A. \& Sales Civera, J.M., Sustainable limits for golf course development in a tourist destination. World review of science. Technology and Sustainable Development, 3(3), pp. 197-210, 2006.

http://doi.org/10.1504/WRSTSD.2006.010221

[2] Wheeler, K. \& Nauright, J., A global perspective on the environmental impact of golf. Sport in Society, 9(3), pp. 427-443. http://doi.org/10.1080/17430430600673449

[3] Ramírez-Hurtado, J.M. \& Berbel-Pineda, J.M., Identification of segments for overseas tourists playing golf in Spain: a latent class approach. Journal of Hospitality Marketing \& Management, 24(6), pp. 652-680.

http://doi.org/10.1080/19368623.2014.934980

[4] Briassoulis, H., Opposition to golf-related tourism development: an interpretivist analysis of an online petition. Journal of Sustainable Tourism, 19(6), pp. 673-693, 2011. http://dx.doi.org/10.1080/09669582.2010.548559

[5] Domínguez, J.A., Análisis socioambiental del golf. ¿Recurso o problema? In Ética y ecología. La responsabilidad social corporativa y la preservación del medio ambiente, ed. L. Galanes, San Juan de Puerto Rico: Tal Cual, 2008.

[6] Baudrillard, J., De la seduction, Editions Galilee: Paris, 1979.

[7] Bourdieu, P., La distinction : critique sociale du jugement, Editions de Minuit, Paris, 1979.

[8] Inglehart, R., Modernization and Postmodernization : Cultural, Economic, and Political Change in 43 Societies, Princeton University Press: Princeton, N.J.

[9] Aledo, A., Reflexiones para una antropología del postdesarrollo. In ed. A. Nogués, Signatura Demos: Sevilla, 2003.

[10] Castro, C.H.A., Turismo deportivo: importancia actual y futura. Retos Turísticos, 8(1), pp. 44-48, 2009.

[11] González, D.G., Pereira, C.G. \& Companioni, C.J.C.H., Vía para la diversificación de un destino Turismo Alternativo. (Spanish). Retos Turísticos, 6(3), pp. 27-34, 2007.

[12] Ceron-Anaya, H., An approach to the history of golf: business, symbolic capital, and technologies of the self. Journal of Sport \& Social Issues, 34(3), pp. 339-358, 2010. http://dx.doi.org/10.1177/0193723510377317

[13] An, M. \& Sage, G.H. The golf boom in South Korea: serving hegemonic interests. Sociology of Sport Journal, 9, pp. 372-372, 1992.

[14] Warnken, J., Thompson, D. \& Zakus, D.H., Golf course development in a major tourist destination: implications for planning and management. Environmental Management, 27(5), pp. 681-696. http://doi.org/10.1007/s002670010179

[15] DeChaine, D.R., From discourse to golf course: the serious play of imagining community space. Journal of Communication Inquiry, 25(2), pp. 132-146. http://doi.org/10.1177/0196859901025002004

[16] Gibbons, M., Limoges, C., Nowotny, H., Schwartzman, S., Scott, P. \& Trow, M., The new production of knowledge: the dynamics of science and research in contemporary societies. Sage Publications, 1994, available at http://search.proquest.com/docview/60 055305 ?accountid $=14549$ 
[17] Flyvbjerg, B., Real Social Science Applied Phronesis, Cambridge University Press, 2012, available at http://www.cambridge.org/us/academic/subjects/sociology/researchmethods-sociology-and-criminology/real-social-science-applied-phronesis

[18] Briassoulis, H., Golf-centered development in coastal Mediterranean Europe: a soft sustainability test. Journal of Sustainable Tourism, 15(5), pp. 441-462.

http://doi.org/10.2167/jost722.0

[19] Khalifa, K., Social constructivism and the aims of science. Social Epistemology, 24(1), pp. 45-61.

http://doi.org/10.1080/02691721003632818

[20] Flyvbjerg, B., Clegg, S.R. \& Haugaard, M., Reflections on phronetic social science: a dialogue between Stewart Clegg, Bent Flyvbjerg, and Mark Haugaard (SSRN Scholarly Paper No. ID 2460651). Social Science Research Network: Rochester, NY, available at http://papers.ssrn.com/abstract=2460651

[21] Flyvbjerg, B., Five misunderstandings about case-study research. Qualitative Inquiry, 12(2), pp. 219-245. http://doi.org/10.1177/1077800405284363

[22] Muhr, T., ATLAS/ti-A prototype for the support of text interpretation. Qualitative Sociology, 14(4), pp. 349-371. http://doi.org/10.1007/BF00989645

[23] Gray, S.A., Zanre, E. \& Gray, S.R.J., Fuzzy cognitive maps as representations of mental models and group beliefs. In Fuzzy Cognitive Maps for Applied Sciences and Engineering, ed. E.I. Papageorgiou, Springer Berlin: Heidelberg, pp. 29-48, available at http:// link.springer.com/chapter/10.1007/978-3-642-39739-4_2

[24] Wodak, R. \& Meyer, M., Methods for Critical Discourse Analysis, SAGE, 2009.

[25] Corbin, J. \& Strauss, A., Grounded theory research: procedures, canons, and evaluative criteria. Qualitative Sociology, 13(1), pp. 3-21, 1990. http://dx.doi.org/10.1007/BF00988593

[26] Villar-Lama, A., Territorio, turismo y paisaje: el proceso de urbanización en el litoral de Andalucía. El papel de los campos de golf, Consejería de Turismo, Comercio y Deporte: Sevilla, 2012.

[27] IECA, I. de E. y C. de A. Sistema de Información Multiterritorial de Andalucía, 2014.

[28] Aledo, A., From the land to ground: The transformation of the landscape and the new residential tourism. Arbor, 184(729), pp. 99-113, 2008. http://dx.doi.org/10.3989/arbor.2008.i729.164

[29] Desse, R.-P. \& Meur-Ferec, C., Golf in france: stakes in real estate. Annales de Geographie, 579, pp. 471-490, 1994. http://dx.doi.org/10.3406/geo.1994.13803

[30] Woodside, A.G., Applying systems thinking to sustainable golf tourism. Journal of Travel Research, 48(2), pp. 205-215, 2009. http://dx.doi.org/10.1177/0047287509332335 